ADAM ŚWIEŻYŃSKI

\title{
Marian Grabowski, Pierwociny stworzenia. Pomiędzy filozofią a fizyką, Wydawnictwo Naukowe UMK, Toruń 2019, ss. 188.
}

Wśród rozmaitych zagadnień i problemów, jakimi zajmują się filozofia religii i filozofia Boga, znajduje się także filozoficzny namysł nad treściami tekstu biblijnego. Jednym z jego przejawów są próby interpretacji historii biblijnych, poprzez które, na drodze hermeneutyki i filozofii biblijnej, poszukuje się pogłębionych i uniwersalnych znaczeń obecnych w Biblii symboli1. Także najnowsza książka Mariana Grabowskiego może zostać zakwalifikowana do tzw. filozofii biblijnej, czyli nurtu filozoficznego odczytywania tekstu biblijnego $\mathrm{i}$ interpretowania jego znaczenia przy użyciu kategorii filozoficznych. Jednocześnie publikacja ta podejmuje także problematykę z zakresu filozofii przyrody z racji wyraźnie obecnych w niej prób filozoficznego uchwycenia i przedstawienia istoty rzeczywistości materialnej. Autor pracy w ten właśnie sposób zmierzył się z początkowym fragmentem biblijnej Księgi Rodzaju ( $\operatorname{Rdz} 1,1-10)$, chcąc ustalić i ukazać głębię znaczenia tego tekstu, jego filozoficzne konotacje, a także dokonać jego reinterpretacji w świetle kategorii filozoficznych wyodrębnionych na gruncie matematyczno-fizykalnego obrazu świata. Celem autora

1 Przykładowo: A. Lacocque, P. Ricoeur, Myśleć biblijnie, tłum. z ang. E. Mukoid, M. Tarnowska, Znak, Kraków 2003; M. Grabowski, Historia upadku. Ku antropologii adekwatnej, WAM, Kraków 2006; M. Szamot, Oto ty, Adamie, WAM, Kraków 2010; E. Schweid, The Philosophy of the Bible, Academic Studies Press, Boston 2009; Y. Hazony, The Philosophy of Hebrew Scripture, Cambridge University Press, New York 2012; J. Gericke, The Hebrew Bible and Philosophy of Religion, Society of Biblical Literature, Atlanta 2012; D. Johnson, Biblical Knowing. A Scriptural Epistemology of Error, Cascade Books, Eugene 2013; A. Świeżyński, The Loneliness of "Adam". An Attempt at Symbolic Interpretation, Laval théologique et philosophique 72(2016)2, 285-297. 
było więc interpretacyjne odsłonięcie metafizyki początku Genesis oraz wygenerowanie metafor bazujących na koncepcjach fizykalnych i matematycznych, które wyrażałyby treści metafizyczne obecne $\mathrm{w}$ analizowanym tekście.

Drogą do zrealizowania wspomnianego zamysłu stało się ukazanie na gruncie dosłowności tekstu jego porządku symbolicznego i odczytanie tej symboliki w kluczu kategorii filozoficznych, takich jak: nieskończoność, niemożliwość, nicość, konieczność, prawdopodobieństwo i innych. Tak określone zasadnicze zadanie hermeneutyczne, tzn. odcyfrowanie symboliki początku Genesis w języku filozoficznym i jej wyrażenie za pomocą zmetaforyzowanych pojęć współczesnego matematycznego przyrodoznawstwa, autor pracy zrealizował w następujących po sobie „krokach” ujętych w dwóch zasadniczych częściach pracy: Interpretacja filozoficzna (Rdz 1,1-10) i Wyktadnia (Rdz 1,1-10) inspiracja dla refleksji filozoficznej. Uzupełnieniem całości rozważań są cztery apendyksy, w których autor rozbudował i uzupełnił niektóre wątki z głównych części pracy. Taką strukturę pracy należy uznać, w świetle podjętej tematyki i z perspektywy potencjalnego odbiorcy, za bardzo interesującą. Pozwala ona zarówno czytelnikowi zaawansowanemu filozoficznie, jak i po prostu zainteresowanemu tematem przyswoić sobie najważniejsze idee i wnioski autora. Wprawdzie druga część pracy jest mocno nasycona treściami matematycznymi i fizykalnymi, ale zostały one zaprezentowane w sposób możliwie przystępny, wydaje się więc, że czytelnik, który zada sobie nieco trudu, aby z uwagą prześledzić tok rozumowania autora, nie powinien mieć poważniejszych trudności w jego zrozumieniu.

Interpretacja $\mathrm{Rdz}$ 1,1-10 przedstawiona w części pierwszej jest niezwykle interesująca i inspiruje czytelnika do dalszych własnych przemyśleń. Wykracza ona znacząco poza standardowo przyjęte rozumienie biblijnego opowiadania o stworzeniu świata, odsłaniając pogłębioną, przemyślaną i oryginalną perspektywę rozumienia tekstu. Zaproponowana interpretacja nie jest przy tym radykalnie 
dowolna i aprioryczna, wiernie trzyma się treści tekstu, choć nie czyni tego w sposób dosłowny. Jak każda prawdziwa interpretacja zawiera w sobie znaczący element subiektywności, ale jest jednocześnie odpowiednio uzasadniona (m.in. bierze pod uwagę kontekst historyczno-kulturowy powstania tekstu) i charakteryzuje się spójnością oraz konsekwencją, dzięki czemu jest wiarygodna - przekonuje, a nawet uwodzi swoim pięknem. Obraz, który się z niej wyłania to metafizyczna rzeczywistość aktu stwarzania świata przez Boga (stwarzania, a nie stworzenia, bo sposób ujęcia przez autora kategorii dotyczących tego aktu sugeruje jego trwanie). Jest on daleki od naiwnego antropomorfizmu i anachronicznego wizerunku wszechmocnego Boga-Stwórcy, który po prostu stworzył coś z niczego. Obraz stworzenia w zaproponowanej interpretacji został mocno wysubtelniony dzięki zwróceniu uwagi na występujące w tekście terminy, które autor pracy rozumie jako symbole odnoszące się do negatywnych źródeł bytu, posiadające swoje pozytywne odpowiedniki bytowe i swoją wykładnię filozoficzną. Ostatecznie więc rozumienie aktu stwórczego ulega znaczącemu pogłębieniu, nabiera niejako dodatkowych wymiarów, które dawniej ukryte „w ciemnościach” teraz zostają wydobyte na światło dzienne, a dzięki kolejnym zabiegom interpretacyjnym autora staje się podstawą do rozważań prowadzonych w dalszej części książki.

W drugiej części autor próbuje wskazać na kontynuacje inspiracji, które biorą się z przedstawionej wykładni Rdz 1,1-10. Jak wspomniano, jest to wykładnia dostarczająca wielu ożywczych impulsów dla rozważań nad kategoriami: przypadku, nieskończoności, konieczności, prawdopodobieństwa. Materiałem dla kontynuowania tych rozważań są dla autora inspiracje zaczerpnięte z matematyki, fizyki i kosmologii przyrodniczej, w których znajduje on podobne idee do tych, które były przedmiotem rozważań w części pierwszej. Zatem w drugiej części książki centralne znaczenie ma idea matematycznej i metafizycznej metafory, która jest przedstawiana i dyskutowana w różnych ujęciach. Autor tworzy filozofię prawdopodobieństwa, filozofię nieskończoności, filozofię przypadku, filozofię konieczności 
inspirowane $z$ jednej strony kategoriami wyekstrahowanymi z interpretacji tekstu biblijnego, a z drugiej - matematyczno-fizykalnymi obrazami dostarczanymi przez nauki. Druga część pracy jest z pewnością bardziej wymagająca dla czytelnika, zwłaszcza nieobeznanego z zagadnieniami matematycznymi. Jednak nawet $\mathrm{w}$ takim przypadku rozumowanie autora, dzięki jego konsekwencji, klarowności i dodatkowym wyjaśnieniom, jest możliwe do prześledzenia i pozwala na uchwycenie nowych aspektów prezentowanych kategorii metafizyki stwarzania. Genezyjskie symbole, wyodrębnione w części pierwszej, zyskują nowe profile wskutek powiązania ich z obrazami zaczerpniętymi z matematyki i fizyki. W ten sposób autor uzyskuje kolejny efekt będący celem pracy, mianowicie nietrywialne, metodologicznie poprawne i światopoglądowo ważne uzgodnienie biblijno-teologicznego obrazu pochodzenia świata $z$ naukowo-przyrodniczym obrazem jego natury. Oczywiście, takich prób łączenia obu obrazów było i nadal jest wiele. Jednak propozycja autora wyróżnia się na ich tle metodologicznym uporządkowaniem (wnioski uzyskane przez niego są wynikiem analiz przeprowadzonych na płaszczyźnie filozofii, do której uprzednio zostają sprowadzone ustalenia interpretacyjne i inspiracje matematyczno-fizykalne) oraz ostrożnością w wyprowadzaniu definitywnych wniosków i swoistym „niedomknięciem” perspektywy. Jest to zaleta, gdyż po pierwsze autor unika stylu twierdząco-ostatecznego, zabójczego dla jakiejkolwiek myśli filozoficznej, a po drugie pozostawia czytelnikowi swobodę i miejsce na kontynuowanie rozpoczętych przez siebie rozważań: niejako wskazuje drogę, którą uważa, że warto byłoby pójść w dalszej wędrówce bez przesądzania, jaki powinien być jej punkt docelowy. Ten ostatni aspekt wyraża się także w ostatnim $\mathrm{z}$ apendyksów, w którym język literatury i wytworzony przezeń obraz poetycki stają się kolejną perspektywą dla analizy kategorii filozoficznych wychwyconych w tekście Genesis. W ten sposób autor zdaje się sygnalizować i dowartościowywać jeszcze inny typ ludzkiej wrażliwości, obok teologicznego i naukowego, który może okazać się przydatny w filozoficznych rozważaniach nad początkiem. 
Omawianą publikację należy uznać za bardzo udaną próbę filozoficznej interpretacji $\mathrm{Rdz}$ 1,1-10 połączoną z uwzględnieniem naukowego obrazu świata wynikającego ze współczesnej matematyki i fizyki, dającą w efekcie racjonalny, przekonujący oraz twórczy względem teologii stworzenia wynik w postaci wielowymiarowego i dogłębnego zaprezentowania istoty biblijnej idei stwarzania świata przez Boga. Niewątpliwie stanowi ona także nowe i twórcze ujęcie problematyki relacji między obrazami świata: biblijno-teologicznym i wynikającym z ustaleń nauk przyrodniczych. Jej swoisty charakter przejawia się $w$ oryginalnym odczytaniu (interpretacji) wybranego fragmentu biblijnego (Rdz 1,1-10) ze świadomym uwzględnieniem przede wszystkim głębokiej symboliki tekstu, w opracowaniu i użyciu metody interpretacyjnej będącej własną propozycją autora, w umiejętnym i twórczym powiązaniu wniosków wyprowadzonych z interpretacji tekstu biblijnego $\mathrm{z}$ naukowym obrazem świata proponowanym przez współczesną fizykę i matematykę w celu ukazania ich spójności przy zachowaniu metodologicznej i epistemologicznej odrębności, i wreszcie w ożywczym impulsie, jakiego dostarcza współczesnej filozofii przyrody, wskazując na tekst biblijny jako możliwe źródło inspiracji dla rozważań prowadzonych w jej ramach.

Dotychczasowe, znane mi interpretacje początku Genesis koncentrują się zazwyczaj wokół analiz historyczno-krytycznych tekstu biblijnego, odczytywaniu wspomnianego fragmentu zgodnie z zasadami i metodami teologii biblijnej albo procedury egzegezy biblijnej o charakterze ogólnoteologicznym. Filozoficzne odczytywanie treści biblijnych początku Ksiegi Rodzaju zaprezentowane przez autora Pierwocin stworzenia jest raczej rzadko spotykane nawet w literaturze obcojęzycznej, a na gruncie polskim właściwie nieobecne (z wyjątkiem publikacji M. Szamot, Genesis. Czy ktoś w to jeszcze wierzy?, WAM, Kraków 2003, która nie jest jednak w pełni interpretacją filozoficzną, choć zawiera jej elementy i do takiej inspiruje). Należy przy tym podkreślić, że propozycja M. Grabowskiego jest oryginalna także w stosunku do innych tego rodzaju opracowań i pod wieloma 
względami filozoficznie bardziej wnikliwa. Nowe ujęcie podjętego problemu polega więc na ukazaniu za pomocą metody interpretacji filozoficznej głębi treści i znaczeń interpretowanego fragmentu biblijnego (pierwsza część pracy), a następnie na dokonaniu reinterpretacji tekstu w świetle metafor zaczerpniętych z języka matematyki i fizyki współczesnej (część druga). Takie ujęcie tytułowego zagadnienia pozwoliło autorowi zaproponować własną, oryginalną i śmiałą (choć dającą się uzgodnić z wcześniejszymi rozumieniami tekstu - przynajmniej niektórymi) wykładnię Rdz 1,1-10, której podstawowymi zaletami są: uchwycenie głębi znaczeń poszczególnych elementów biblijnego obrazu stwarzania świata przez Boga; całościowość, spójność i logiczna konsekwentność zaproponowanej wykładni; powiązanie obrazu biblijnego ze współczesnym obrazem naukowym dzięki sprowadzeniu obu na wspólną płaszczyznę filozoficzną; ukazanie Rdz 1,1-10 jako tekstu, który ma w sobie znaczny potencjał eksplikacyjny, istotny z punktu widzenia człowieka usiłującego zrozumieć istotę otaczającego go świata, sposób jego funkcjonowania oraz chcącego racjonalnie wyjaśnić jego genezę.

Dodatkowym istotnym elementem nowego ujęcia problemu, którego dotyczy treść omawianej książki, jest obecność w niej wątku egzystencjalnego, związanego z ludzkim codziennym doświadczeniem (wątek ten pojawia się w różnym miejscach; niekiedy jest tylko delikatnie sygnalizowany i pozwala czytelnikowi kontynuować rozważania nad nim niejako "na własną rękę" w stylu zaproponowanym przez autora, a znajduje swoje zwieńczenie w apendyksie nr 4). Egzystencjalne interpretowanie tekstu biblijnego spotykane obecnie w literaturze i w innych formach przekazu bywa zwykle ograniczane do tekstów fabularnych (tzn. tych, które zawierają w sobie jakąś akcję z udziałem postaci biblijnych) albo do tekstów mądrościowych i wypowiedzi pouczających. W dodatku interpretacja egzystencjalna jest najczęściej dość powierzchowna, nazbyt dosłowna (niekiedy wręcz banalna) i nie wnika w głębię symboliki tekstu, skupiając się głównie na wątkach religijno-moralno-etycznych. Marianowi Grabowskiemu 
udało się nie tylko dokonać interpretacji tekstu z pozoru nie-egzystencjalnego, która posiada walor egzystencjalny, ale także przeprowadzić ją tak, że wnioski z niej płynące stanowią niebanalne, realistyczne, a zarazem wykraczające poza empirię ujęcie ludzkiego doświadczenia. Wnioski wyprowadzone $\mathrm{z}$ analizy kategorii: nieskończoności, prawdopodobieństwa, konieczności, możliwości i in. znalazły swój ostateczny punkt odniesienia w ludzkim doświadczeniu życiowym i pozwalają spojrzeć na nie w odświeżonej perspektywie ludzkiego samorozumienia i egzystencjalnie doniosłych prób odnajdywania się w świecie mnogości (nieskończoności?) rzeczy, plątaniny (prawdopodobieństwa?) zdarzeń i złożoności (przypadkowości?) relacji.

Należy także podkreślić, że książka została napisana językiem bardzo komunikatywnym i obrazowym, do czego M. Grabowski zdążył nas już przyzwyczaić swoimi wcześniejszymi publikacjami². Narracja tekstu jest prowadzona w taki sposób, że skłania czytelnika do własnego namysłu oraz pobudza jego uwagę dzięki zastosowaniu środków stylistycznych, które nadają tekstowi charakter dynamicznej, fascynującej opowieści przy jednoczesnym zachowaniu jego w pełni naukowego, filozoficznego charakteru. Warto jeszcze nadmienić, że materiał graficzny umieszczony w książce jest pomocny w pełniejszym uchwyceniu toku myśli autora oraz ułatwia czytelnikowi zrozumienie tekstu, zwłaszcza fragmentów zawierających nawiązania do matematyki i fizyki. Zaproponowane schematy dobrze ilustrują wywody autora.

Na zakończenie warto odnotować jedną uwagę o charakterze uzupełniającym treść publikacji. Wydaje się, że cenne byłoby dodanie jeszcze jednego apendyksu, w którym zaprezentowane i zanalizowane uprzednio kategorie powiązane $\mathrm{z}$ aktem stwórczym zostałyby jeszcze wyraźniej ukierunkowane teologiczno-egzystencjalnie. Mam

2 Zob. m.in. M. Grabowski, Pomazaniec. Przyczynek do chrystologii filozoficznej, w drodze, Poznań 2010; Tenże, Miłość seksualna, Wydawnictwo Naukowe UMK, Toruń 2012; Tenże, Egzegeza filozoficzna początku Genesis, Studia Philosophiae Christianae 53(2017)1, 35-58. 
na myśli ukazanie przede wszystkim ich teologicznego (ale jednocześnie religijno-egzystencjalnego) aspektu, czyli waloru religijno-egzystencjalnego zaproponowanej interpretacji początku Genesis. $\mathrm{Na}$ przykład religijno-egzystencjalna konsekwencja zaproponowanej przez autora interpretacji ciemności jako niemożliwości versus możliwości: nie przesądzajmy zbyt łatwo o niemożliwości czegoś (miejsce [możliwość] na akt wiary); religijno-egzystencjalna konsekwencja przeprowadzonej interpretacji rozróżnienia między niemożliwym a nieprawdopodobnym: mamy prawo oczekiwać rzeczy nieprawdopodobnych (miejsce [możliwość] na akt nadziei); religijno-egzystencjalna konsekwencja dokonanej interpretacji możliwości i konieczności: możliwość pojawienia się czegoś nie oznacza konieczności zaistnienia czegoś - potrzebny jest jeszcze akt czyjejś woli (miejsce [możliwość] na akt miłości). Powyższa uwaga jest jedynie skromną sugestią (a może także delikatną zachętą) do kontynuacji przez autora zaprezentowanych rozważań i do przygotowania kolejnego tekstu, który od filozoficznej interpretacji pierwocin stworzenia mógłby przeprowadzić czytelnika do równie interesującej i inspirującej interpretacji jego dalszych owoców i ich egzystencjalnie doniosłych następstw.

\footnotetext{
ADAM ŚWIEŻYŃSKI

a.swiezynski@uksw.edu.pl

Uniwersytet Kardynała Stefana Wyszyńskiego w Warszawie, Instytut Filozofii

Wóycickiego 1/3, 01-938 Warszawa

ORCID: 0000-0003-0430-4530
}

DOI: 10.21697/spch.2020.56.1.31 